\title{
ANALISIS FUNGSI KAWASAN DENGAN PENERAPAN SISTEM INFORMASI GEOGRAFIS DI WILAYAH KOTA SORONG PROVINSI PAPUA BARAT
}

\author{
Irnawati \\ Universitas Muhammadiyah Sorong, Indonesia
}

\begin{abstract}
Analysis of Area Function by Application of Geographical Information Systems in Sorong City, West Papua Province. This study aimed to determine the condition of land use and physical state of the appropriate factual condition then gave a number of areas scored on a map of annual rainfall, slope and soil types to produce an overlay zoning district functions, then overlaid with maps of land use generated temporary spatial plan then analyzed the suitability of land use with the regional spatial plan of Sorong in 2004. Data collected into tables and maps were described qualitatively descriptive in order to obtain a view of area function suitability with the characteristics of the region. Based on the results of valuation analysis (slope, rainfall and soil type), there were three zoning areas function, i.e the protected areas covering an area of 80.36 $\mathrm{km}^{2}$, forest cultivation area $158.57 \mathrm{~km}^{2}$ and non-forest area cultivation 105.56 $\mathrm{km}^{2}$. The results of analysis of Ikonos imagery interpretation of the path/row $107-$ 61 was obtained that 12 of the land use pattern in Sorong City in the form of dryland primary forest, secondary dry land forest, airport, primary mangrove forests, primary swamp forests, gardens, sand, settlement, dryland agriculture, grass/shrubs, ponds and wasteland. Status of land with the direction of temporary spatial plans of Sorong City which within the spatial plans of Sorong City in 2004 was not appropriate, which was meant that the condition of land use incompatible with the area function, but supposedly would not cause a significant impact due to land use not in conflict with the function of region. Based on the results of the analysis, there was over functions as large as $77.21 \mathrm{~km}^{2}(22.87 \%)$.
\end{abstract}

Kata kunci: fungsi kawasan, sistem informasi geografi, Sorong

Sampai dengan tahun 2005, lahan di wilayah Provinsi Papua Barat yang digunakan sebagai pemukiman terletak pada lahan-lahan di wilayah Kota Sorong dengan luas lahan pemukiman wilayah Kota Sorong mencapai $49 \%$ dari seluruh luas lahan pemukiman di Provinsi Papua Barat (Anonim, 2006 ${ }^{\mathrm{a}}$ ). Wilayah Kota Sorong merupakan pintu gerbang bagi Provinsi Papua Barat yang telah tumbuh menjadi sentral-sentral kegiatan perkotaan berupa kegiatan jasa, perdagangan dan kegiatankegiatan lain terkonsentrasi di wilayah ini. Sementara itu, Manokwari adalah kabupaten yang menjadi ibukota Provinsi Papua Barat.

Berdasarkan Anonim $\left(2006^{\mathrm{b}}\right)$, untuk menghindari terjadinya ketimpangan dalam pelaksanaan pembangunan di semua sektor, maka pembangunan dan pengelolaan sumberdaya alam yang sifatnya beragam harus dilakukan secara proporsional. Hal ini akan dapat dilaksanakan bila ruang wilayah di setiap daerah telah ditata peruntukannya dan untuk memaksimalkan penggunaannya disusun peta perwilayahan berdasarkan kesesuaian fungsi dan tata guna lahan dengan mempertimbangkan berbagai aspek. 
Wujud struktural pemanfaatan ruang adalah susunan unsur-unsur pembentuk rona lingkungan alam, lingkungan sosial dan lingkungan buatan yang secara hirarki dan struktural berhubungan satu dengan yang lainnya membentuk tata ruang. Wujudnya antara lain pola lokasi, sebaran pemukiman, industri, perdagangan serta bentuk pemanfaatan lahan lainnya, baik di pedesaan maupun di perkotaan. Tambunan dan Setiadarma (1997) menyatakan, tujuan utama dari penataan ruang adalah untuk:

a. Terselenggaranya pemanfaatan ruang berwawasan lingkungan yang berlandaskan wawasan nusantara.

b. Terselenggaranya pengaturan pemanfaatan ruang kawasan lindung dan kawasan budidaya.

c. Tercapainya pemanfaatan ruang yang berkualitas.

Salah satu klasifikasi penataan ruang adalah penataan ruang yang berdasarkan fungsi utama kawasan, meliputi kawasan lindung, kawasan budidaya kehutanan dan kawasan non budidaya kehutanan.

Wilayah Kota Sorong telah melaksanakan penataan ruang yang dituangkan dalam Rencana Umum Tata Ruang Wilayah (RUTR) Kota Sorong 1992-2002. Konsep dasar RTRW Kota Sorong mengacu pada Undang-undang Penataan Ruang (UUPR), namun begitu penerapannya banyak mengalami hambatan yang dikarenakan ketidaksiapan lembaga dalam menangani penataan ruang serta kurangnya kesadaran masyarakat dalam memahami kebijakan/aturan-aturan yang telah ditetapkan (Anonim, 2002). Salah satunya adalah pemanfaatan lahan yang kurang sesuai dengan rencana tata ruang wilayah, antara lain adanya pemukiman pada sempadan sungai ataupun sempadan laut, kawasan lindung terdapat pemukiman dan sebagainya. Sekalipun pemerintah daerah telah berupaya dalam mengatasi penyimpangan-penyimpangan yang terjadi namun akan sulit terwujud bila bertambahnya jumlah penduduk tidak dapat dikendalikan (Anonim, 2002).

Pengelolaan sumberdaya alam ke depan perlu didukung oleh prakondisi yang mantap dan terencana, antara lain perlunya ketersediaan data dan informasi yang akurat dan mutakhir mengenai kondisi sumberdaya alam setempat terutama hubungannya dengan karakteristik wilayah yang bersangkutan yaitu topografi, jenis vegetasi, keadaan tanah, iklim dan keadaan sosial ekonomi (Anonim, 2002).

Untuk keperluan tersebut maka pemanfaatan sistem informasi geografis (SIG) untuk pengelolaan data dan informasi yang bersifat keruangan adalah sangat tepat. Dengan SIG ini maka data dan informasi tentang sumberdaya hutan dan kawasan ini dapat disimpan, diolah, dianalisis dan ditampilkan dengan mudah dan cepat.

Bertitik tolak pada kerangka pemikiran, maka penelitian ini bertujuan untuk mengetahui kondisi pemanfaatan lahan secara faktual sesuai keadaan fisik dan kondisi wilayah, kemudian memberikan angka skoring pada peta curah hujan tahunan, peta kelerengan dan peta jenis tanah untuk di overlay menghasilkan zonasi fungsi kawasan; petunjuk teknis ini ditetapkan berdasarkan kebijaksanaan Kawasan Lindung Kepres No. 32 Tahun 1990 dan SK Menteri Pertanian No. $837 / \mathrm{Kpts} / \mathrm{Um} / 1980$ tetang kriteria penetapan kawasan lindung dan budidaya, selanjutnya peta zonasi fungsi kawasan ditumpangsusunkan (overlay) dengan pemanfaatan lahan menghasilkan rencana tata ruang wilayah sementara yang 
kemudian dianalisis kesesuaian menggunakan lahan tersebut dengan rencana tata ruang wilayah Kota Sorong Tahun 2004, sehingga memberikan arahan perencanaan tata ruang wilayah sesuai dengan kondisi fisik dan pemanfaatan lahan.

\section{METODE PENELITIAN}

Data yang dikumpulkan ke dalam bentuk tabel dan peta diuraikan secara deskriptif kualitatif, sehingga diperoleh gambaran mengenai kesesuaian fungsi kawasan dengan karakteristik wilayahnya. Penelitian dilaksanakan di wilayah Kota Sorong Provinsi Papua Barat selama \pm 5 bulan sejak bulan Februari sampai dengan Juli 2011 .

Bahan yang digunakan dalam penelitian ini merupakan data spasial dan tabular yang meliputi data fisik dan data sosial. Peta analog diperoleh dari Kantor Bappeda Kota Sorong, Kementerian Kehutanan Kota Sorong, Badan Pertanahan Kota Sorong, serta Kantor Walikota Sorong, sedangkan data tabular diperoleh dari buku Kota Sorong dalam angka tahun 2011, buku laporan akhir RTRW Kota Sorong tahun 2002-2012 serta buku Rencana Detail Tata Ruang Wilayah Kota Sorong tahun 2006-2011

Pemetaan kawasan meliputi kegiatan input data melalui pendigitasian peta-peta analog/tematik dan data tabular. Digitasi dilakukan dengan menggunakan perangkat lunak Arcview GIS Versi 3,3.

Pemetaan pemanfaatan lahan dari peta landsat path 107-061 diinterpretasikan menghasilkan peta pemanfaatan lahan kemudian menghitung luas masing-masing kawasan sesuai fungsinya pada peta fungsi kawasan hasil tumpang susun peta kelerengan, peta jenis tanah dan data curah hujan berdasarkan nilai skoring.

Perhitungan nilai skoring mengacu pada tiga faktor yang dinilai sebagai penentu kemampuan lahan, yaitu kelerengan, jenis tanah menurut kepekaan terhadap erosi dan intensitas curah hujan tahunan.

Dari peta kelas kelerengan, jenis tanah dan curah hujan yang diterbitkan oleh Bappeda Kota Sorong tahun 2008 skala 1 : 250.000, maka diperoleh pengelompokkan dengan klasifikasi seperti pada Tabel 1, 2 dan 3.

Melalui overlay peta masing-masing faktor di atas, didapatkan satuan-satuan lahan menurut klasifikasi dan nilai skor tersebut. Penetapan fungsi kawasan dilakukan dengan menjumlahkan nilai skor dari ketiga faktor yang dinilai pada setiap satuan lahan. Besarnya jumlah nilai skor tersebut merupakan nilai skor kemampuan lahan untuk masing-masing satuan lahan. Perhitungan nilai skor suatu kawasan adalah sebagai berikut:

Skor $=$ BNT FKL + BNT FKT + BNT FKCH. BNT $=$ Bobot Nilai Tertimbang, FK $=$ faktor Kelas Lereng. FKT $=$ faktor kelas tanah. $\mathrm{FKCH}=$ faktor Kelas Curah Hujan.

Kriteria dan tata cara penetapan arahan fungsi kawasan pemanfaatan lahan untuk setiap satuan lahan diklasifikasi berdasarkan penentuan kawasan hasil skoring (Tabel 4). 
Tabel 1. Klasifikasi Kelas Lereng Lapangan dan Bobot Nilai Tertimbang

\begin{tabular}{cclc}
\hline Kelas lereng & Kelerengan $(\%)$ & Kriteria & BNT \\
\hline I & $0-8$ & Datar & 20 \\
II & $>8-15$ & Landai & 40 \\
III & $>15-25$ & Agak curam & 60 \\
IV & $>25-40$ & Curam & 80 \\
V & $>40$ & Sangat curam & 100 \\
\hline
\end{tabular}

Sumber: Anonim (1980)

Tabel 2. Klasifikasi Nilai Skor Faktor Jenis Tanah Menurut Kepekaan Tanah terhadap Erosi dan Bobot Nilai Tertimbang

\begin{tabular}{|c|c|c|c|}
\hline $\begin{array}{l}\text { Kelas } \\
\text { tanah }\end{array}$ & Jenis tanah & Kriteria & BNT \\
\hline I & Aluvial & Tidak peka & 15 \\
\hline II & Aluvial latosol & Kurang peka & 30 \\
\hline III & Latosol & Agak peka & 45 \\
\hline IV & Podsolik coklat kelabu, podsol, renzina, litosol & Peka & 60 \\
\hline $\mathrm{V}$ & Podsolik merah kuning, litosol, regosol & Sangat peka & 75 \\
\hline
\end{tabular}

Sumber: Anonim (1980)

Tabel 3. Klasifikasi Curah Hujan dan Bobot Nilai Tertimbang

\begin{tabular}{cclc}
\hline Kelas curah hujan & $\begin{array}{c}\text { Rata-rata curah hujan } \\
\text { tahunan }(\mathrm{mm})\end{array}$ & Kriteria & BNT \\
\hline I & $500-1.000$ & Rendah & 10 \\
II & $>1.000-1.500$ & Sedang & 20 \\
III & $>1.500-2.000$ & Agak tinggi & 30 \\
IV & $>2.000-2.500$ & Tinggi & 40 \\
V & $>2,500$ & Sangat tinggi & 50 \\
\hline
\end{tabular}

Sumber: Anonim (1980)

Tabel 4. Penentuan Kawasan Hasil Skoring

\begin{tabular}{|c|c|c|}
\hline Kawasan & Jumlah skor & Kriteria \\
\hline $\begin{array}{l}\text { Kawasan } \\
\text { lindung }\end{array}$ & $>175$ & $\begin{array}{l}\text { Kemiringan lereng }>40 \text { (sangat curam) } \\
\text { Kelas jenis tanah sangat peka (regosol, litosol, organosol, redsina). } \\
\text { Curah hujan }>2500 \mathrm{~mm} / \mathrm{tahun} . \\
\text { Merupakan jalur pengamatan aliran sungai. } \\
\text { Topografi } 2000 \mathrm{~m} \text { dpl. } \\
\text { Penutupan lahannya } 75 \% \text {. }\end{array}$ \\
\hline $\begin{array}{l}\text { Kawasan } \\
\text { budidaya } \\
\text { kehutanan }\end{array}$ & $124-174$ & $\begin{array}{l}\text { Kelerengan 15-25 (curam). } \\
\text { Kelas jenis tanah peka (podsolik merah kuning, litosols). } \\
\text { Lokasi secara ekonomis mudah dikembangkan sebagai kawasan } \\
\text { penyangga. } \\
\text { Tidak merugikan segi-segi ekologi/lingkungan hidup bila } \\
\text { dikembangkan sebagi kegiatan tanaman industri. } \\
\text { Kegiatan utama berupa perhutanan, perikanan, pertambangan dan } \\
\text { peternakan. }\end{array}$ \\
\hline $\begin{array}{l}\text { Kawasan } \\
\text { budidaya non } \\
\text { kehutanan }\end{array}$ & $<124$ & $\begin{array}{l}\text { Untuk pemukiman dan pembangunan perkotaan perkantoran, } \\
\text { perdagangan dan jasa, pariwisata, serta industri. } \\
\text { Kemiringan }<8 \%\end{array}$ \\
\hline
\end{tabular}

Sumber: Anonim (1980 dan 1990) 
Analisis tumpangsusun dari berbagai peta adalah untuk mendapatkan gambaran umum serta menyeluruh mengenai keadaan wilayah Kota Sorong, terutama penggunaan lahan dan kesesuaiannya dengan fungsi kawasan yang dituangkan dalam peta arahan penyusunan rencana tata ruang wilayah Kota Sorong. Sesuai dengan kriteria yang telah ditentukan dalam menentukan zonasi kawasan lindung dan kawasan budidaya di Kota Sorong atas Keppres No. 32 tahun 1990 tentang pengelolaan kawasan lindung. Selain itu adanya ketentuan-ketentuan pada UU RI No. 41 tentang kehutanan (pasal 18 ayat 2), guna mengoptimalisasi manfaat lingkungan, manfaat sosial dan manfaat ekonomi masyarakat setempat, maka upaya pengembangan Kota Sorong diarahkan untuk dapat mempertahankan kecukupan luas kawasan hutan sekurang-kurangnya 30\% luas yang ada di Kota Sorong.

\section{HASIL PENELITIAN DAN PEMBAHASAN}

Berdasarkan peta paduserasi fungsi kawasan hasil skoring yang dianalisis menggunakan sistem informasi geografis (SIG), yang mana sistem analisisnya menggunakan:

1. Intensitas curah hujan. Intensitas hujan tahunan rata-rata diperoleh berdasarkan perhitungan data selama 10 tahun (2001-2010) yang diperoleh dari Stasiun Badan Meteorologi \& Geofisika Kota Sorong. Dengan intensitas curah hujan rata-rata tahunan $>2500 \mathrm{~mm} /$ tahun, Kota Sorong termasuk mempunyai curah hujan sangat tinggi. Karena intensitas curah hujan terdapat pada satu stasiun maka diasumsikan nilai intensitas curah hujan sama dengan luas lokasi penelitian yaitu $344,49 \mathrm{~km}^{2}$.

2. Kelerengan. Berdasarkan hasil analisis dan pengamatan di lapangan, terdapat 5 kelas lereng di wilayah Kota Sorong, yaitu: lereng datar (I) dengan skor 20, lereng landai (II) dengan skor 40 menempati bentuk lahan dataran aluvial, lereng agak curam (III) dengan skor 60, lereng curam (IV) dengan skor 80 dan lereng sangat curam (V) dengan skor 100 yang menempati bentuk lahan tanggul alam.

3. Kelas tanah. Kelas tanah yang dimaksud di sini adalah kelas tanah terhadap bahaya erosi. Hasil analisis laboratorium dari penelitian sebelumnya dan pengecekan ulang di lapangan, diperoleh bahwa tanah yang ditemui adalah alluvial, termasuk tanah kelas I dengan skor 15; kambisols, termasuk tanah kelas III dengan skor 45; podsolik, termasuk tanah kelas IV dengan skor 60; regosols/litosol, termasuk tanah kelas $\mathrm{V}$ dengan skor 75. Luas tanah berdasarkan erodibilitasi atau kepekaan tanahnya, didominasi oleh tanah yang sangat peka (kelas V) terhadap bahaya erosi dengan luas $103,83 \mathrm{~km}^{2}$ dan tanah yang agak peka (kelas III) terhadap erosi dengan luas $109,01 \mathrm{~km}^{2}$, sedangkan sisanya terdiri dari kelas tanah peka (kelas IV) dengan luas $77,57 \mathrm{~km}^{2}$ dan kelas tanah tidak peka (kelas I) dengan luas $3,47 \mathrm{~km}^{2}$.

Dari hasil analisis dan tumpangsusun diketahui, bahwa Kota Sorong dibagi menjadi 3 zonasi fungsi kawasan, yaitu kawasan lindung di wilayah Kota Sorong seluas $80,36 \mathrm{~km}^{2}(23,33 \%)$, kawasan budidaya kehutanan seluas $158,57 \mathrm{~km}^{2}$ $(46,03 \%)$ dan kawasan budidaya non kehutanan seluas $10,56 \mathrm{~km}^{2}(30,64 \%)$ dari luas keseluruhan wilayah Kota Sorong $344,49 \mathrm{~km}^{2}$. 


\section{Analisis Pemanfaatan Lahan}

Pemanfaatan lahan di wilayah Kota Sorong berdasarkan hasil analisis digitasi peta citra landsat quick bird dikelompokkan menjadi 12 kelas pemanfaatan lahan di wilayah Kota Sorong.

1. Hutan lahan kering primer dan hutan lahan kering sekunder. Kawasan berhutan yang terdapat di wilayah Kota Sorong terdiri dari hutan lahan kering primer dan hutan lahan kering sekunder. Klasifikasi hutan lahan kering primer seluas 116,08 $\mathrm{km}^{2}(33,70 \%)$. Hutan lahan kering primer dapat menjadi indikasi bahwa kawasan tersebut tidak terganggu yang disebabkan oleh aktivitas manusia dan bencana alam. Hutan lahan kering sekunder dengan luas 108,88 km² (31,61\%).

2. Hutan mangrove primer dan hutan rawa primer. Batas wilayah Kota Sorong sebelah utara berupa garis bentang pantai pesisir Provinsi Papua Barat. Berdasarkan hasil interpretasi, bentang pesisir yang seharusnya masih berupa tutupan vegetasi mangrove telah mengalami perubahan akibat aktivitas manusia di sekitar wilayah pesisir Kota Sorong. Perubahan yang terjadi berupa pemukiman yang ditempati oleh para nelayan, konversi mangrove menjadi lahan terbuka dan tambak. Luas tutupan mangrove primer yang terdapat pada bentang pesisir wilayah Kota Sorong seluas $17,79 \mathrm{~km}^{2}(5,17 \%)$ dari luas total 344,49 wilayah Kota Sorong. Kemudian disusul pemanfaatan lahan hutan rawa primer yaitu sebesar $0,52 \mathrm{~km}^{2}$ atau sekitar $0,15 \%$.

3. Pertanian lahan kering, perkebunan dan pasir. Jenis pemanfaatan lahan berupa pertanian lahan kering seluas $70,52 \mathrm{~km}^{2}(20,47 \%)$, pasir $0,56 \mathrm{~km}^{2} \quad(0,16 \%)$, perkebunan 4,82 $\mathrm{km}^{2}(1,40 \%)$; perkebunan di wilayah Kota Sorong tingkat kesuburannya cukup bervariasi, tetapi di beberapa tempat merupakan lahan-lahan subur bagi sektor perkebunan yang didominasi oleh coklat, cengkeh, salak maupun buah-buahan lainnya.

4. Pemukiman dan bandar udara. Pemukiman di Kota Sorong seluas $20,52 \mathrm{~km}^{2}$ $(5,96 \%)$. Peningkatan jumlah penduduk tentunya disertai peningkatan kebutuhan akan tempat tinggal. Pola pemukiman di dataran cenderung berdekatan (berkelompok), sedangkan pemukiman di daerah perbukitan atau pegunungan 0-8\% cenderung terpencar (terpisah-pisah). Pemanfaatan lahan yang berkembang di kawasan Bandar Udara Domine Edward Osok (DEO) Sorong didominasi oleh kegiatan perkantoran, perdagangan dan jasa, terlihat dari semakin banyaknya pembangunan pertokoan dan perkantoran baru. Luas kawasan Bandar Udara DEO Kota Sorong $0,84 \mathrm{~km}^{2}(0,24 \%)$.

5. Tambak, semak belukar dan tanah terbuka. Pemanfaatan lahan di Kota Sorong berupa kawasan tambak adalah seluas $0,53 \mathrm{~km}^{2}(0,15 \%)$, semak belukar 2,95 $\mathrm{km}^{2}$ $(0,86 \%)$. Pemanfaatan lahan berupa rumput/semak belukar dan tanah terbuka perlu menjadi perhatian karena dapat mengakibatkan penurunan kualitas lahan yang berpotensi menjadi lahan kritis. Tanah terbuka adalah seluas $0,47 \mathrm{~km}^{2}(0,14 \%)$. Penyebab dari semak belukar dan tanah terbuka yang luas karena adanya aktivitas manusia seperti penebangan hutan dan ladang berpindah yang ditinggalkan. 


\section{Analisis Arahan RTRW Sementara Kota Sorong}

Peta arahan RTRW Sementara Kota Sorong diperoleh melalui tahap tumpang susun peta fungsi kawasan hasil skoring dan peta pemanfaatan lahan, dari peta arahan RTRW sementara tersebut memiliki luas fungsi kawasan lindung 135,34 $\mathrm{km}^{2}$ $(39,29 \%)$, kawasan budidaya kehutanan $108,77 \mathrm{~km}^{2}$ (31,57\%) dan kawasan budidaya non kehutanan $100,37 \mathrm{~km}^{2}(29,14 \%)$. Kriteria pemanfaatan lahan yang masuk pada kawasan lindung, kawasan budidaya kehutanan dan kawasan budidaya non kehutanan dapat dilihat pada Tabel 5.

Tabel 5. Zonasi Fungsi Kawasan Terhadap Pemanfaatan Lahan

\begin{tabular}{lclrr}
\hline \multirow{2}{*}{ Zonasi fungsi kawasan } & \multirow{2}{*}{ No } & \multicolumn{2}{c}{ Pemanfaatan lahan } & \multicolumn{2}{c}{ Luas } \\
\cline { 4 - 6 } Kawasan lindung & 1 & Bandar udara & 0,84 & \multicolumn{1}{c}{$\mathrm{km}^{2}$} \\
& 2 & Hutan lahan kering primer & 116,08 & 33,70 \\
& 3 & Hutan mangrove primer & 17,79 & 5,17 \\
& 4 & Hutan rawa primer & 0,53 & 0,15 \\
\hline Kawasan budidaya kehutanan & 5 & Hutan lahan kering sekunder & 108,88 & 31,61 \\
\hline Kawasan budidaya non kehutanan & 6 & Kebun & 4,82 & 1,40 \\
& 7 & Pasir & 0,56 & 0,16 \\
& 8 & Pemukiman & 20,52 & 5,96 \\
& 9 & Pertanian lahan kering & 70,52 & 20,47 \\
& 10 & Rumput/semak belukar & 2,95 & 0,86 \\
& 11 & Tambak & 0,53 & 0,15 \\
& 12 & Tanah kosong & 0,47 & 0,14 \\
\hline Jumlah & & & 344,48 & 100,0 \\
\hline
\end{tabular}

Pada Tabel 5 terlihat, bahwa setelah ditumpangsusunkan peta pemanfaatan lahan dan peta hasil skoring, luas kawasan lindung meningkat, hal ini disebabkan karena hutan lahan kering primer yang berada di wilayah Kota Sorong seluas 116,08 $\mathrm{km}^{2}$, ini berarti $33,70 \%$ hutan lahan kering primer berada di kawasan lindung, Bandar Udara DEO Kota Sorong dengan luas $0,84 \mathrm{~km}^{2}(0,24 \%)$, disusul jenis pemanfaatan lahan hutan rawa primer yaitu sebesar $0,52 \mathrm{~km}^{2}(0,15 \%)$ dan hutan mangrove primer $17,79 \mathrm{~km}^{2}(5,17 \%)$ yang masuk sebagai kawasan lindung.

Luas kawasan budidaya kehutanan menjadi $108,88 \mathrm{~km}^{2}$, hal ini disebabkan adanya alih fungsi kawasan tersebut menjadi hutan lahan kering sekunder. Luas kawasan budidaya non kehutanan menjadi $100,37 \mathrm{~km}^{2}$, hal ini disebabkan semakin meningkatnya pemanfaatan lahan seperti kebun, pasir, pemukiman, pertanian lahan kering, rumput atau semak belukar, tambak dan tanah kosong.

\section{Analisis RTRW Kota Sorong 2004}

Dari analisis peta RTRW Kota Sorong tahun 2004 diketahui, bahwa Kota Sorong dibagi menjadi 3 kawasan, yaitu: kawasan lindung dengan luas $160,38 \mathrm{~km}^{2}$, kawasan budidaya kehutanan $122,34 \mathrm{~km}^{2}$ dan kawasan budidaya non kehutanan $61,77 \mathrm{~km}^{2}$. 


\section{Analisis Alih Fungsi Kawasan}

Kawasan lindung berdasarkan hasil analisis sistem informasi geografis semakin berkurang sebesar 7,72\%. Demikian juga yang terjadi pada kawasan budidaya kehutanan berkurang sebesar 3,94\% sedangkan kawasan budidaya non kehutanan bertambah sebesar $11,21 \%$. Hal tersebut disebabkan selain tuntutan pembangunan dan meningkatnya jumlah penduduk dari tahun ke tahun menyebabkan kebutuhan akan lahan untuk pemukiman, lahan pertanian, perkebunan menjadi semakin meningkat.

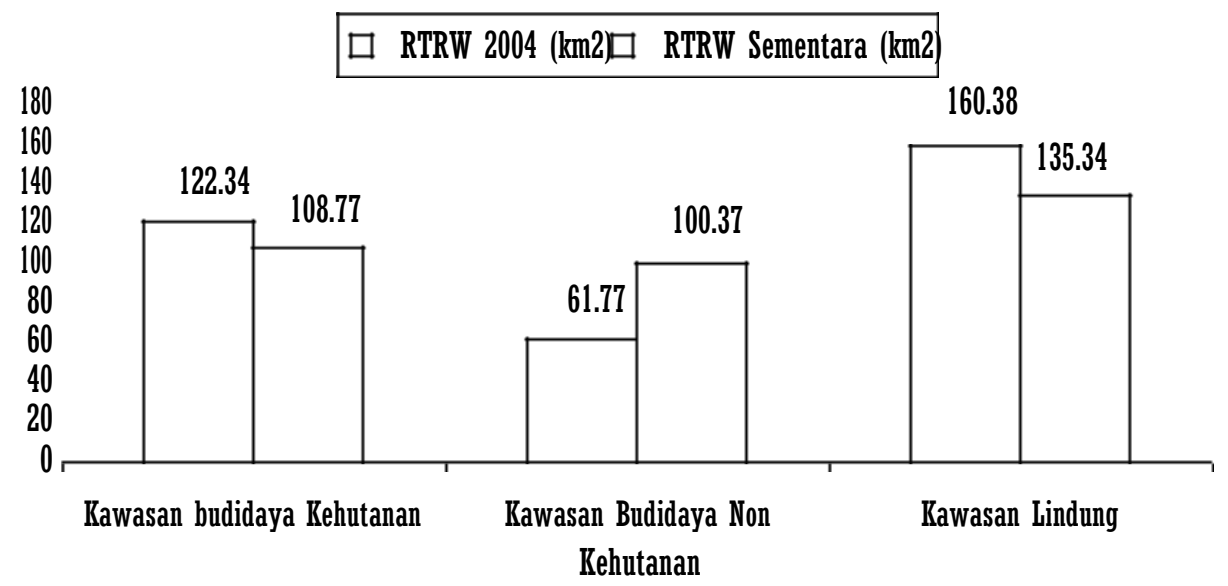

Gambar 1. Perbandingan Zonasi Fungsi Kawasan RTRW 2004 dan RTRW Sementara

Pada Gambar 1 terlihat perbandingan fungsi kawasan RTRW Kota Sorong tahun 2004 dengan RTRW Sementara saat ini belum sesuai dengan fungsi kawasan, namun diduga tidak akan menimbulkan dampak yang berarti, sebab alih fungsi kawasan tersebut tidak terlalu bertentangan dengan masing-masing fungsi kawasan.

Terdapat beberapa ketidaksesuaian pada fungsi kawasan, yaitu:

1. Adanya alih fungsi kawasan lindung (7,27\%) menjadi kawasan budidaya kehutanan dan kawasan budidaya non kehutanan di Kota Sorong. Kawasan budidaya berorientasi kepada pengembangan pemanfaatan potensi sumberdaya alam, peningkatan perekonomian dan kesejahteraan masyarakat melalui penetapan teknologi yang sesuai dan ramah lingkungan, sedangkan pada kawasan budidaya non kehutanan dapat dialihfungsikan menjadi kawasan pertanian lahan kering, perkebunan, peternakan serta perikanan, di mana dapat dimanfaatkan potensi sumberdaya wilayah secara optimal dan tidak menimbulkan konflik dengan pemanfaatan lainnya seperti kawasan yang diperuntukan bagi pertanian lahan kering untuk tanaman palawija, holtikultural/tanaman tahunan. Kawasan budidaya non kehutanan secara indikatif terdapat pada seluruh distrik Kota Sorong. Permasalahan yang terjadi adalah bagaimana meningkatkan hasil pertanian tetapi pada saat yang sama keberadaan sumberdaya alam tetap terjaga. 
2. Alih fungsi kawasan budidaya kehutanan $(3,94 \%)$ dan kawasan budidaya non kehutanan $(11,21 \%)$ menjadi kawasan lindung di Kota Sorong. Alih fungsi kawasan ini disebabkan adanya faktor biogeofisik (pola pemanfaatan lahan, jenis tanah, curah hujan dan kelerengan), sehingga dapat direkomendasikan menjadi kawasan lindung, kawasan budidaya kehutanan dan kawasan budidaya non kehutanan.

\section{Arahan Perencanaan Tata Ruang}

\section{Wilayah 1. Pemanfaatan lahan}

Pemanfaatan lahan di Kota Sorong didominasi oleh hutan lahan kering primer. Pemanfaatan lahan kawasan lindung yaitu bandar udara, hutan lahan kering primer, hutan mangrove primer, hutan rawa primer. Pemanfaatan lahan pada kawasan budidaya non kehutanan yaitu kebun, pasir, pemukiman, pertanian lahan kering, semak belukar, tambak dan tanah kosong, sedangkan kawasan budidaya kehutanan didominasi oleh hutan lahan kering sekunder. Kondisi ini perlu mendapat perhatian dari pemerintah Kota Sorong dalam menjaga dan mengelolanya, yang mana sumberdaya alam memiliki peranan strategis sebagai penyangga kehidupan serta memberikan nilai manfaat yang meliputi aspek ekologi, sosial dan ekonomi.

\section{Arahan fungsi kawasan tata ruang}

Di wilayah Kota Sorong terdapat 3 zonasi fungsi kawasan untuk arahan RTRW Kota Sorong seperti pada Tabel 6.

Tabel 6. Arahan Rencana Tata Ruang Wilayah Kota Sorong

\begin{tabular}{lcc}
\hline \multirow{2}{*}{ Zonasi } & \multicolumn{2}{c}{ Luas } \\
\cline { 2 - 3 } & Arahan RTRW $\left(\mathrm{km}^{2}\right)$ & $(\%)$ \\
\hline Kawasan Budidaya Kehutanan & 108,47 & 31,49 \\
Kawasan Budidaya Non Kehutanan & 70,84 & 20,56 \\
Kawasan Lindung & 165,17 & 47,95 \\
\hline Jumlah & 344,49 & 100,00 \\
\hline
\end{tabular}

a. Arahan penataan ruang kawasan lindung. Dari ketetapan RTRW tahun 2004, bahwa kawasan lindung Kota Sorong adalah seluas 160,38 km² (46,56\%). Arahan penataan ruang direkomendasikan menjadi $165,17 \mathrm{~km}^{2}(47,95 \%)$, di mana kawasan wilayah Kota Sorong sebagian besar wilayahnya termasuk dalam kawasan lindung. Menurut Peraturan Pemerintah No. 47 Tahun 1997, bahwa kawasan lindung adalah kawasan yang ditetapkan dengan fungsi utama melindungi kelestarian lingkungan hidup yang mencakup sumberdaya alam, sumberdaya buatan dan nilai sejarah serta budaya bangsa, guna kepentingan pembangunan berkelanjutan.

Arahan umum pengelolaan kawasan lindung menurut Anonim $\left(2006^{\mathrm{b}}\right)$ adalah: i) pemantapan batas dan status kawasan lindung sehingga keberadaannya lebih jelas baik secara fisik maupun hukum; ii) pemanfaatan kawasan lindung dapat dilakukan sejauh tidak mengurangi fungsi lindungnya; iii) mengikutsertakan masyarakat lokal dalam pemeliharaan kawasan lindung; iv) pengelolaan 
kawasan lindung yang meliputi lebih dari satu wilayah administrasi, baik dari segi fisik maupun fungsional di bawah koordinasi pemerintah kota.

b. Kawasan budidaya kehutanan. Arahan fungsi kawasan budidaya kehutanan adalah 108,47 km² (31,49\%), di mana berdasarkan ketetapan RTRW Kota tahun 2004 bahwa kawasan budidaya kehutanan memiliki luas 122,34 km². Dari hasil verifikasi lapangan berkurangnya kawasan budidaya kehutanan lebih dipengaruhi oleh semakin meluasnya kawasan pemukiman, tambak dan perkebunan.

Arahan umum pengelolaan kawasan budidaya kehutanan adalah: i) Sorong penetapan kawasan budidaya kehutanan sesuai fungsi; ii) semaksimal mungkin diarahkan untuk dapat memberikan kontribusi peningkatan pendapatan masyarakat yang kegiatannya meliputi kegiatan kawasan budidaya kehutanan;

iii) menjamin keberadaan hutan tetap dengan luas yang cukup sebagai penyangga kehidupan; iv) mengoptimalkan fungsi kawasan budidaya kehutanan meliputi fungsi konservasi dan fungsi produksi, sehingga diperoleh manfaat lingkungan, sosial, budaya dan ekonomi yang seimbang dan lestari; v) menjamin distribusi manfaat hutan yang berkeadilan dan berkelanjutan.

c. Kawasan budidaya non kehutanan. Arahan fungsi kawasan budidaya non kehutanan adalah seluas $70,84 \mathrm{~km}^{2}(20,56 \%)$, di mana berdasarkan ketetapan rencana tata ruang wilayah Kota Sorong tahun 2004 kawasan budidaya non kehutanan memiliki luas $61,77 \mathrm{~km}^{2}$. Dari hasil verifikasi lapangan luas kawasan budidaya non kehutanan ini lebih dipengaruhi oleh kegiatan pemukimanpemukiman baru, pasir dan perkebunan atau kegiatan-kegiatan lain yang mengarah pada peningkatan kawasan budidaya non kehutanan, sehingga diarahkan kepada pengembangan untuk wilayah perkotaan serta peningkatan sarana dan prasarana umum.

\section{KESIMPULAN DAN SARAN}

\section{Kesimpulan}

Berdasarkan hasil analisis skoring peta (kelerengan, curah hujan dan jenis tanah) terdapat tiga zonasi fungsi kawasan yaitu zonasi fungsi kawasan lindung seluas $80,36 \mathrm{~km}^{2}$, kawasan budidaya kehutanan seluas $158,57 \mathrm{~km}^{2}$ dan kawasan budidaya non kehutanan seluas $105,56 \mathrm{~km}^{2}$, sedangkan hasil analisis interpretasi peta citra ikonos path/row 107-61 didapatkan 12 pola pemanfaatan lahan di wilayah Kota Sorong berupa hutan lahan kering primer, hutan lahan kering sekunder, bandar udara, hutan mangrove primer, hutan rawa primer, kebun, pasir, pemukiman, petanian lahan kering, rumput/semak belukar, tambak dan tanah kosong.

Status lahan dengan arahan rencana tata ruang wilayah sementara Kota Sorong pada rencana tata ruang wilayah Kota Sorong tahun 2004 tidak sesuai dengan fungsi kawasan, namun diduga tidak akan menimbulkan dampak yang berarti, sebab pemanfaatan lahan tidak terlalu bertentangan dengan fungsi kawasannya. Berdasarkan hasil analisis alih fungsi luas yang terjadi sebesar $77,21 \mathrm{~km}^{2}(22,87 \%)$, di mana kawasan budidaya kehutanan 3,94\%, kawasan lindung 7,72\% dan kawasan budidaya non kehutanan $11,21 \%$. 
Sesuai dengan kondisi fisik dan pemanfaatan lahan terdapat tiga zonasi fungsi kawasan untuk arahan RTRW Kota Sorong yaitu kawasan lindung 165,17 km² $(47,95 \%)$, kawasan budidaya kehutanan $108,47 \mathrm{~km}^{2}(31,49 \%)$ dan kawasan budidaya non kehutanan $70,84 \mathrm{~km}^{2}(20,56 \%)$ dari seluruh luas wilayah Kota Sorong $344,49 \mathrm{~km}^{2}$.

\section{Saran}

Arahan pemanfaatan ruang masih perlu digali lebih lanjut mengingat kondisi dan potensi daerah berbeda-beda dan memerlukan penanganan yang maksimal. Agar dapat memberikan manfaat, maka arahan pilihan pemanfaatan lahan dapat diaplikasikan secara nyata sebagai bentuk dalam mewujudkan pemanfaatan potensi lahan dan kelestarian lingkungan.

\section{DAFTAR PUSTAKA}

Anonim. 1980. Keputusan Menteri Pertanian RI No. 837/Kpts/Um/II/1980 tentang Kriteria dan Tata Cara Penetapan Kawasan Hutan Lindung.

Anonim. 1990. Keputusan Presiden RI Nomor 32 Tahun 1990 tentang Pengelolaan Kawasan Lindung.

Anonim. 2002. Integrasi Teknik Interpretasi Visual Citra Landsat 7 ETM+ dengan Menggunakan Sistem Informasi Geografis untuk Pemetaan Tutupan Lahan. Forest Watch Indonesia, Dept. GIS.

Anonim. 2006 ${ }^{\mathrm{a}}$. Irian Jaya Barat dalam Angka. Biro Pusat Statistik Provinsi Irian Jaya Barat.

Anonim. 2006 ${ }^{\mathrm{b}}$. Rencana Detail Tata Ruang Wilayah Kota Sorong Tahun 2006-2011, Laporan Akhir Bappeda Kota Sorong

Tambunan, L.R. dan R. Setiadarma. 1997. Image Enhancement and Classification for Remote Sensing Data Interpretation. (Introduction to Remote Sensing and GIS Course 1-2 December 1997). 
